\title{
RESEARCH OF PLUM DRYING PROCESS
}

\author{
Nurlan Kurmanov ${ }^{1}$, Azret Shingissov ${ }^{2}$, Gulzhan Kantureyeva ${ }^{3}$, Zeinep Nurseitova ${ }^{4}$, Baurzhan \\ Tolysbaev $^{5}$, Gulzhanat Shingisova ${ }^{6}$
}

\begin{abstract}
In this study, the drying kinetics of a domestic plum cultivar were examined in a laboratory scale hotair dryer, SHS-80, at an air velocity of $0.65 \mathrm{~m} \mathrm{~s}^{-1}$ and within the air temperature range of $45-75{ }^{0} \mathrm{C}$. It was found that the whole fruit dried the best. Also, the study assessed the influence of the drying method on the quality of the domestic plum cultivar. Dried fruits were assessed for sensory parameters and ascorbic acid content. Studies have shown that the proposed method of drying, yields a higher ascorbic acid content for the dried product than the conventional approach.
\end{abstract}

UDC Classification: 664.8, DOI: http://dx.doi.org/10.12955/cbup.v3.643

Keywords: Drying, Moisture Content, Moisture Evaporation, Dried Plum, Ascorbic Acid.

\section{Introduction}

Increasing demand for high-quality dried products requires the development, modeling, and further optimization of the drying process, not only for the effectiveness of the process, but for ensuring the quality of the final product.

Plums, as well as other fruits and berries that grow in southern Kazakhstan in large numbers, are a source of biologically useful substances. At the same time, due to the seasonality of the product, there is a need to store raw fruit products, in order to preserve the maximum content of biologically-active substances, which decrease from the slightest tissue injury or brief exposure to rise in temperature.

Drying is one of the most common and well-known methods of preservation and processing of agricultural raw materials.

Drying raw vegetable matter involves a complex heat and mass diffusion process that involves two paths: thermophysically and technologically.

The thermophysical drying process determines the transfer of heat and moisture inside the product, while the technological one is a set of moisture and heat exchanges that result in physical, structural, chemical, and nutrient transformations (Gabas, Menegalli, Ferrari, \& Telis-Romero,, 2002; Bahar, Yousefi, \& Nateghi, 2013).

The speed and nature of these processes determine the quality of the finished product. The selection of a drying method depends on the structure of the raw material, its chemical composition, and the stability of the biologically-active substances.

One way to reduce the time taken for the drying process is to pre-shred the fruit. However, several studies have shown that oxidative processes intensify in crushed fruit, contributing to the loss of valuable nutrients (Tarhan, 2007; Techaena, Lebert, \& Bimbenet, 1991; Hepbasli, Colak, Hancioglu, Icier, \& Erbay, 2010; Goyal, Kingsly, Manikantan, \& Ilyas, 2007). Additionally, the cutting of fruit into halves may significantly increase surface evaporation, and restrict the movement of moisture. Hence, it is better to dry whole fruit, because the increase of moisture per unit of surface evaporation, impairs the moisture movement from the deeper layers to the surface.

While the drying of fruit offers products with extended shelf-life, the quality of the product may be less than that of fresh foodstuff. Therefore, it is essential to maximize the nutrient retention during the

\footnotetext{
${ }^{1}$ Nurlan Kurmanov, Kazakh University of Economics, Finance and International Trade, n.a.kurman@mail.ru

${ }^{2}$ Azret Shingissov, M. Auezov South Kazakhstan State University, Shymkent, Kazakhstan

${ }^{3}$ Gulzhan Kantureyeva, M. Auezov South Kazakhstan State University, Shymkent, Kazakhstan

${ }^{4}$ Zeinep Nurseitova, M. Auezov South Kazakhstan State University, Shymkent, Kazakhstan

${ }^{5}$ Baurzhan Tolysbaev, L. N. Gumilyov Eurasian National University, Astana, Kazakhstan, tolysbaev_b@enu.kz

${ }^{6}$ Gulzhanat Shingisova, L. N. Gumilyov Eurasian National University, Astana, Kazakhstan
} 
drying process (Raynal, Moutounet, \& Souquet, 1989; Kurozawa, Hubinger, \& Park, 2012; Sabarez, 2012).

Ascorbic acid is considered an indicator of the quality of the food product during processing and storage. If ascorbic acid is well retained, then other nutrients are also well retained. Therefore, studying the influence of the drying conditions and methods that can potentially retain ascorbic acid in plums is of paramount importance.

Hence, the aim of this current work is to study the effect of drying on the fruit, in terms of kinetics and quality of the end product.

\section{Materials and methods}

In order to investigate the process of drying plums, the most widespread cultivar in the South Kazakhstan region, with a late ripening period, Vengerka domestic, was chosen. Matured samples, without any structural deformation, as determined by a sensory analysis, were collected.

Moisture content was determined in the selected fruit by drying samples to a constant weight. The initial moisture content for the plums was $89 \pm 0.5 \%$.

Before drying, plums were sorted by size. Next, to remove the waxy coating, plums were treated in boiling water for $10-20$ seconds, and then slightly dried. The fruit were then loaded onto a sieve of a SHS-80 dryer and treated with convective hot-air drying at $45-75^{\circ} \mathrm{C}$, and air-flow velocity equal to $0.65 \mathrm{~m} \mathrm{~s}^{-1}$.

At the initial stage, plums were dried at $45-55^{\circ} \mathrm{C}$ for $6-7$ hours, and then at $70-75{ }^{\circ} \mathrm{C}$. To reach a uniform drying of the plums during the drying process, samples were taken out of the dryer and cooled several times, so as not to dry out the surface layers of the fruit.

Using the initial moisture content of the plums, the moisture content $(W)$ at any time in the process relative to the pre-drying state was calculated using the following formula:

$$
W=\frac{G_{1}-G_{t}}{G_{1}} \cdot 100
$$

where, $\mathrm{G}_{\mathrm{t}}$ - sample weight at any moment $(g)$

$\mathrm{G}_{1}$ - sample weight prior to drying $(g)$

\section{Results and Discussion}

\section{Drying characteristics}

The graphical representation of the relationship between the moisture content and the drying time, and a plot showing the dynamics of evaporation from the surface of plum are shown in Figures 1 and 2.

The drying curve analysis shows that the dried plums, like other types of plant material, were characterized by three main periods of drying: warm up, constant rate of drying, and a falling rate of drying. As can be seen from Figure 1, the start region, which corresponded to accelerated moisture evaporation from the plums, relates to the period of plum warming (from 0 to $17 \mathrm{~min}$ ), when evaporation occurred from the surface layers of the samples.

Next, followed a period of drying at a constant rate (17 to $245 \mathrm{~min}$ ), during which moisture diffused from the inner layers, i.e. the concentration of moisture in the inner and outer layers of the plum tended to even out. During this period, $70-75 \%$ of the moisture was removed. Then, a period involving a falling rate of drying began, during which the evaporation of moisture was gradually reduced. 

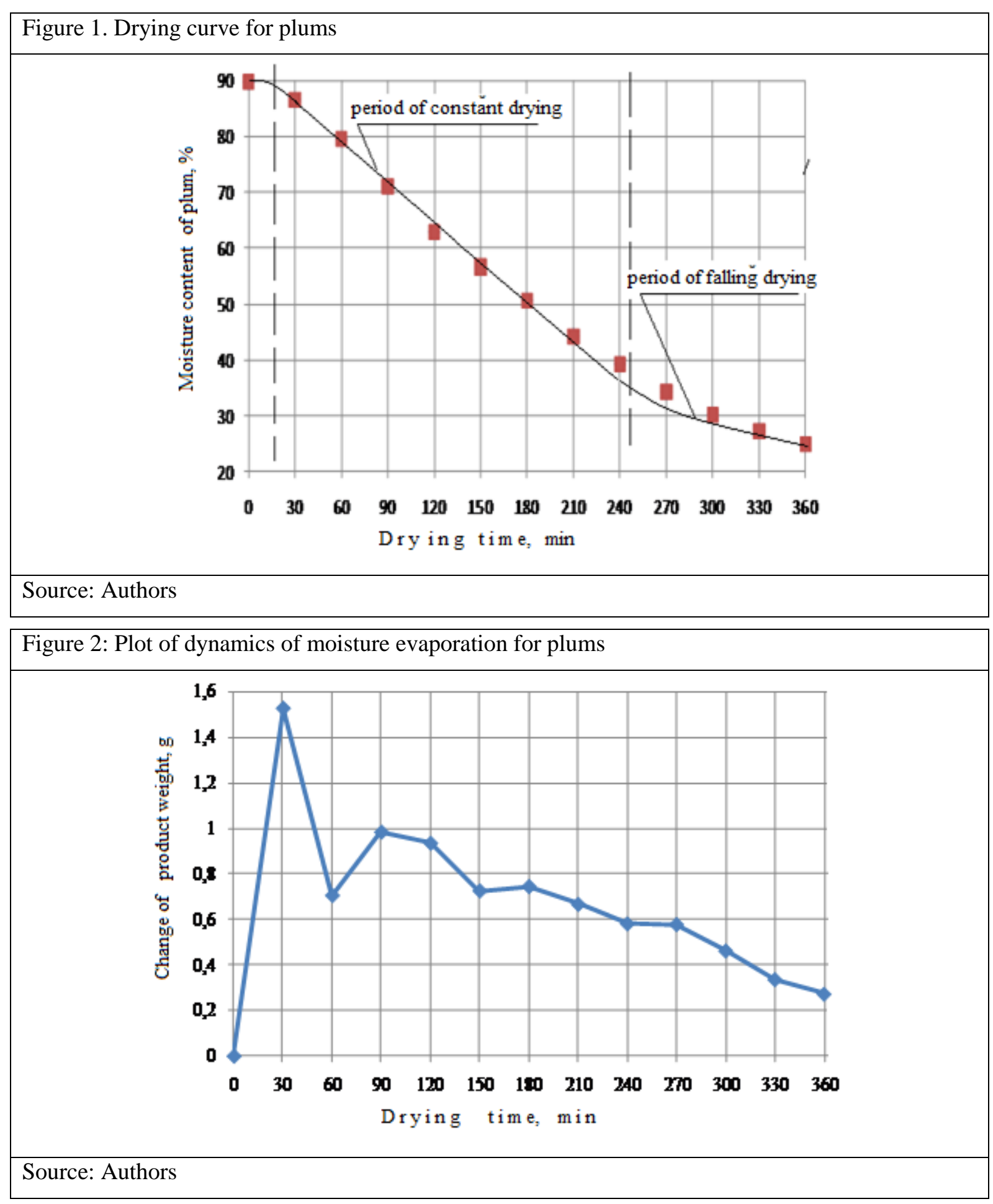

An analysis of the plot relating to the dynamics of moisture evaporation for the plums indicates that the largest evaporation from the plum surface occurred during the time interval between 0 and $30 \mathrm{~min}$. After this, the evaporation of moisture decreased due to the removal of the loosely coupled moisture at the plum surface. In the following period, the drying zone within the product deepened and an equilibrium of moisture content was reached.

Quality characteristics

As is known, the sensory characteristics: color, odor, taste, and consistency, are the most important qualities of dried fruit. The results of quality characteristics for this study of dried plums, using the proposed technique, are shown in Table 1. 


\begin{tabular}{|l|l|}
\hline \multicolumn{2}{|l|}{ Table 1: Indicators of the quality of the dried plum } \\
\hline Name of indicator & \\
\hline $\begin{array}{l}\text { Appearance and } \\
\text { shape }\end{array}$ & $\begin{array}{l}\text { Whole fruit with stones. } \\
\text { Uniform color, black with a bluish tinge, and glossy. }\end{array}$ \\
\hline Taste and aroma & Peculiar to this type of fruit, without foreign flavor and smell \\
\hline $\begin{array}{l}\text { Moisture } \\
\text { content, \% }\end{array}$ & $20-25$ \\
\hline
\end{tabular}

Source: Authors

An analysis of the data in Table 1 shows that the sensory quality of the dried plum meets the technical requirements for dried stone fruit (Euro-Asian Council for Standardization, Metrology and Certification, 1990).

This paper also reported on the ascorbic acid content in the dried plums, as an indicator of the efficiency of the proposed drying method.

The ascorbic acid content of the test samples was determined at the engineering profile regional laboratory, M. Auezov SKSU, using a liquid chromatograph, ProStar Varian. Results of these tests are shown in Table 2.

Table 2. The results of the ascorbic acid content in the fresh and the dried plums

\begin{tabular}{|c|c|c|c|c|}
\hline \multirow{2}{*}{$\begin{array}{c}\text { Plum variety } \\
\text { Vengerka domestic }\end{array}$} & \multirow{2}{*}{$\begin{array}{c}\text { Weight } \\
\text { (g) }\end{array}$} & \multirow{2}{*}{$\begin{array}{c}\text { Moisture } \\
\text { content } \\
(\%)\end{array}$} & \multicolumn{2}{|c|}{$\begin{array}{l}\text { Ascorbic acid content } \\
\text { (mg } 100 \mathrm{~g}^{-1} \text { of product) }\end{array}$} \\
\hline & & & $\begin{array}{c}\text { according to data } \\
\text { of Kurozawa et al. } \\
(2014)\end{array}$ & This study \\
\hline Fresh & 100.0 & 89.9 & 7.60 & 6.50 \\
\hline Dried & 19.5 & 25.0 & 0.60 & 0.62 \\
\hline
\end{tabular}

Source: Author

As indicated by Table 2, the proposed method of drying provides an ascorbic acid content that is more than 3.3\% higher than that of the source data (Kurozawa, Terng, Hubinger, \& Park, 2014). Consequently, the proposed scheme of plum drying is the most effective.

\section{Conclusion}

Thus, on the basis of this research, it is concluded that the application of the proposed method of drying, in practice, provides a better quality product for conserving biological nutrients. An analysis of the plot relating to the dynamics of moisture evaporation for the plums indicates that the largest evaporation from the plum surface occurred during the time interval between 0 and $30 \mathrm{~min}$. After this, the evaporation of moisture decreased due to the removal of the loosely coupled moisture at the plum surface. In the following period, the drying zone within the product deepened, and an equilibrium of moisture content was reached.

\section{References}

Bahar, B., Yousefi, M., and Nateghi, L. (2013). Evaluation of drying methods (homemade and industrial) on physicochemical properties of dried sour plum and sloe in Iran. European Journal of Experimental Biology, 3(6), 144-147. 
Euro-Asian Council for Standardization, Metrology and Certification. (1990). Interstate System for Standardization. Standard: GOST 28501-90. Dried fruits. Specifications. Commonwealth of Independent States: Author.

Gabas, A. L., Menegalli, F. C., Ferrari, F., and Telis-Romero, J. (2002). Influence of drying conditions on the rheological properties of prunes. Drying Technology, 20(7), 1485-1502.

Goyal, R. K., Kingsly, A. R. P., Manikantan, M. R., and Ilyas, S. M. (2007). Mathematical modelling of thin layer drying kinetics of plum in a tunnel dryer. Journal of Food Engineering, 79(1), 176-180.

Hepbasli, A., Colak, N., Hancioglu, E., Icier, F., and Erbay, Z. (2010). Exergoeconomic analysis of plum drying in a heat pump conveyor dryer. Drying Technology, 28(12), 1385-1395.

Kurozawa, L. E., Hubinger, M. D., and Park, K. J. (2012). Glass transition phenomenon on shrinkage of papaya during convective drying. Journal of Food Engineering, 108(1), 43-50.

Kurozawa, L. E., Terng, I., Hubinger, M. D., and Park, K. J. (2014). Ascorbic acid degradation of papaya during drying: Effect of process conditions and glass transition phenomenon. Journal of Food Engineering, 123, 157-164.

Raynal, J., Moutounet, M., and Souquet, J. M. (1989). Intervention of phenolic compounds in plum technology. 1. Changes during drying. Journal of Agricultural and Food Chemistry, 37(4), 1046-1050.

Sabarez, H. T. (2012). Computational modelling of the transport phenomena occurring during convective drying of prunes. Journal of food engineering, 111(2), 279-288.

Tarhan, S. (2007). Selection of chemical and thermal pretreatment combination for plum drying at low and moderate drying air temperatures. Journal of food engineering, 79(1), 255-260.

Techaena, O., Lebert, A. M., and Bimbenet, J. J. (1991). Simulation of plum drying in deep bed. Drying Technology, 9(4), 947-971. 